\title{
İzmir bölgesinde mide kanserli olguların göç yerlerine göre değerlendirilmesi: Tek merkez deneyimi
}

\section{Evaluation of gastric cancer patients based on migrants in Izmir: Single center study}

(D) Ayfer SERIN ${ }^{1}$, (D) Sezgin VATANSEVER ${ }^{2}$

Sişli Florence Nigthingale Hastanesi, ${ }^{1}$ Gastroenteroloji Kliniğĭ, Karaciğer Nakli Birimi, Istanbul

Katip Çelebi Universitesi Tip Fakültesi, ${ }^{2}$ Gastroenteroloji Bilim Dal, Izmir

Giriş ve Amaç: Mide kanseri coğrafi bölgelere göre değişen slkllkta görülmektedir. Biz bu çalışmada Izmir'e diğer bölgelerden göç edenlerin mide kanseri görülme sıkllğını ve özelliklerini araştırdık. Gereç ve Yöntem: Hastanemize bassuran ve mide kanseri tanısı alan 20 yaşından büyük hastalarnn verileri retrospektif olarak incelendi. Patolojisi adenokanser olanlar çalışmaya dahil edildi. Yaş, nüfusa kayttl olduklarn illere ve coğrafi bölgelerine, yerleșim yeri özellikleri kent ve kırsal bölge olarak gruplara ayrıldı. Her bir bölgeden mide kanseri görülmesi Adrese Dayalı Nüfus Kayıt Sistemi kayıtlarına göre Izmir'de bulunma nüfusları ile 100000 kişiye düssen oranlar hesaplandı. Her bölge için elde edilen oranlar diğer bölgelerle karșllaștırllip istatistiksel olarak Pearson Korelasyon testi kullanıldl, $p<0.05$ değeri anlamlı kabul edildi. Yas grupları arasında da 20 yaş ile 80 yaş üstüne dek her 10 yılllk periyotlardaki hasta oranları birbirleri karşılaştırıldı. Bulgular: Izmir'e diğer bölgelerden göç edenler arasında mide kanseri görülme sıklğ̆ \%0.027 ile Balkan ülkelerinden gelenler ve \%0.026 ( $p=0.001)$ ile Doğu Anadolu Bölgesinden gelenler arasında görüldü $(p=0.001)$, bu sonuçlar diğer bölgelerin mide kanseri görülme oranları ile karşılaştınldığında yüksek bulundu ve istatistiksel olarak anlamllydı. Tüm hastalar arasında 50 yaş üzerinde olanlarda mide kanseri görülmesi 50 yas altındakine oranla yüksek [50-59 yas ( $p=0.012$ ), 60-69 yas $(p=0.012), 70-79$ yas $(p=0.001)$ ], erkek cinsiyette $(\% 70)$ kadınlardan (\%30) $(p=0.002)$ daha yüksek oranda ve kentsel alanda (\%8.7) yașayanlarda kirsal alanda yaşayanlara göre (\%5.1) ( $p=0.005)$ daha yüksek oranda bulundu. Sonuç: Izmir'e diğer bölgelerden göç edenlerde mide kanseri; 50 yas üzerinde erkeklerde, Doğu Anadolu Bölgesinden, Balkan Ülkelerinden gelen kişiler arasında ve kentsel bölgede yaşayanlarda daha yüksek oranlarda saptandı.

Anahtar kelimeler: Mide kanseri, Izmir, coğrafi bölgeler, göçmen
Background and Aims: The incidence of gastric cancer varies according to geographical regions worldwide. In this study, we investigated the prevalence and characteristics of gastric cancer in migrants from other regions of Izmir. Material and Methods: Data of patients older than 20 years who were admitted to our hospital and diagnosed with gastric cancer were retrospectively reviewed. The population was divided into groups according to their geographical regions, where they were registered. Gastric cancer incidence among migrants from each region according to Address Based Population Registration System records, the population of each region in Izmir, and the rate per 100000 people were calculated. The rates obtained for each region were compared with other regions, and the Pearson correlation test was employed. A value of $p<0.05$ was accepted as statistically significant. Results: The incidence of gastric cancer among immigrants from other regions of Izmir was $0.027 \%$ among those from Balkan countries and $0.026 \%$ among those from Eastern Anatolia. A statistically significant difference was observed upon comparison of the rates of gastric cancer in Eastern Anatolia, Balkan, and other regions ( $p=0.001, p=0.001$, respectively). Overall, the incidence of gastric cancer was higher in patients above age 50 years than those below age 50 years (50-59 years, $60-69$ years, and $70-79$ years: $p=0.012$, $p=0.012$, and $p=0.001$, respectively). Moreover, it was higher in males than females $[70 \%$ and $30 \%$, respectively $(p=0.002)]$, and was higher in the urban area than rural areas $[8.7 \%$ vs. $5.1 \%(p=0.005)]$. Conclusion: The incidence of gastric cancer in migrants from other regions were observed to be higher in males aged above 50 years and among people from Eastern Anatolia Region, Balkan Countries, and those living in urban areas.

Keywords: Gastric cancer, Izmir, geographical regions, migrants

\section{GİRİS ve AMAÇ}

Mide kanseri, tüm kanser türleri arasında en sık görülen 4. malignite olup, kanser kaynaklı ölümlerin de 2. en sık nedenidir (1). Mide kanseri insidansı farklı coğrafi bölgelerinde değişkenlik göstermektedir. Mide kanseri insidansı Japonya, Kore, Çin, Şili, Kosta-Rika ve Brezilya'da 20/100 000 kişi/ yl'dan fazladır. Italya, Ingiltere, Almanya, Hollanda ve Türkiye'nin içinde bulunduğu grup ülkeler ise, 10-20/100 000 kişi/yll ile mide kanseri açısından orta düzeyli insidansa sahiptir. ABD, Kanada, Danimarka, Mısır, Hindistan ve Avustralya ise mide kanseri insidansı açısından 10/100.000 kişi/yll ile düşük insidanslı ülkeler olarak kabul edilmektedir. Bazı ülkelerde, ülkenin değişik bölgelerinde bile mide kanseri görülme sıklığında farklılıklar gözlenebilmektedir (2). Mide

kanseri görülme oranı erkek cinsiyette kadınlara göre ortalama 2 kat daha yüksektir (Erkek/ Kadın oranı; 1.5-2.5/1) $(3,4)$. Avrupa'da yapılan bir çalışmada, mide kanseri insidansının yaşlı popülasyonda (median yaş 62 yll) ve düşük sosyo-ekonomik şartlara sahip kişilerde daha fazla olduğu belirtilmiştir (3). Mide kanserinin toplumlar arasında farklı sıklıkta görülmesinin başlıca nedenleri olarak; diyetteki tuz miktarı, sigara kullanımı, konserve gıda kullanımı, gıdaların korunması için kullanılan kimyasal maddelere maruziyet (nitrat vb), taze sebze ve meyve tüketimindeki farklllıklar, yaşanılan ev ve yaşam koşulları, sosyo-ekonomik düzey, Helicobacter pylori enfeksiyonu sıklığındaki farklılıklar sıralanabilir (2-9). Son ylllarda, gelişmiş ve ülkemiz gibi gelişmekte 
olan ülkelerde metabolik sendrom ve metabolik sendromun hepatik manifestasyonu olarak kabul edilen non-alkolik yağlı karaciğer hastalığı (NAYKH; NAFLD = Non-alcoholic fatty liver disease) sıklığı giderek artmaktadır. Non-alkolik yağlı karaciğer hastalığı alkol tüketim öyküsü olmaksızın karaciğer dokusunun \%5'inden fazlasının yağlanması olarak tanımlanmaktadır ve son 3 dekadda giderek artan sıklığı ile global bir halk sağlığı problemi haline gelmiştir (9). NAYKH ile hem mide ve hem de kolon kanseri gibi gastrointestinal maligniteler arasında ilişki olduğunu, bu nedenle NAYKH'nın da mide kanseri gelişiminde farklı moleküler mekanizmalar aracılığı ile predispozan bir risk faktörü olabileceğini ileri süren çalışmalar mevcuttur (10).

Ülkemiz, mide kanseri insidansı açısından orta riskli ülkeler arasında yer alırken (2), Helicobacter pylori enfeksiyonu açısindan ise yüksek prevalansa sahiptir (11-13). Ayrıca Ebstein Barr virüs ve Herpes simpleks virüs ile mide kanseri gelişimi arasında ilişki bildirilmiştir (14). Mide kanseri anatomik olarak \%35 vakada antrum ve pilorda, \%15 vakada korpusda ve fundusda, \%50 olguda ise kardiyada görülmektedir. Son yıllarda proksimal segment tutulum oranları artmaktadır. Gastrik adenokarsinom (non-kardiya gastrik kanser), gastroözofageal bölge adenokarsinomu olarak ayrılmaktadır. Patolojik olarak midenin malign tümörleri; adenokarsinom, (papiller adenokarsinom, tübüler adenokarsinom, müsinöz adenokarsinom, taşlı yüzük hücreli adenokarsinom), adenoskuamöz karsinom, skuamöz hücreli karsinom, küçük hücreli karsinom, indiferansiye karsinom, ve non-epitelyal (lenfoma ve mezenkimal tümörler) olarak ayrılır (15). Mide kanseri \%90 adenokarsinom olup Leuren siniflamasina göre \%54 intestinal tip, \%32 diffüz tip, \%15 indetermine tip olarak görülmektedir (16). Intestinal tip adenokarsinomun intestinal metaplazi ve Helicobacter pylori ile yakın ilişkili olduğu gösterilmiştir (17).

Malign epitelyal mide tümörleri beslenme durumu, yaş, genetik (18) gibi faktörlerle yakından ilişkilidir. Sosyoekonomik şartlar, diyet, yaşam tarzı açısından bölgeler arası ve kent-kırsal kesimde yaşamaya göre çeşitli farklılıklar mevcuttur. Ülkemizde mide kanseri insidansı açısından yapılmış birçok çalışma mevcuttur.

Bizim çalışmamızın amacı hastanemize başvuran ve mide kanseri (gastrik adenokarsinom) tanısı alan hastaların, ülkemizin 7 bölgesi ve Balkan Ülkelerinden göç ile İmir'e yerleşenler arasında, geldikleri coğrafi bölgelere göre mide kanseri görülme sıklığındaki farklılıklarının araştırılmasıdır.

\section{GEREC ve YÖNTEM}

Hastanemiz Gastroenteroloji Kliniğinde Aralık 2005-Temmuz 2010 arasında endoskopi yapılmış ve mide kanseri saptanan 20 yaşından büyük hastalar çalışmaya dahil edildi. Retrospektif olarak hastaların verileri incelendi. Gastrik lenfoma ve malign stromal tümör olan hastalar çalışma dışı bırakıldı. Gastrik adenokanser tanısı alanlar çalışmaya dahil edildi. Hastaların demografik verileri ve nüfüsa kayıtlı olduğu yerler, adresleri, hangi ilden göç edip geldikleri hasta dosya bilgilerinden, adres ve kimlik bilgilerinden taranarak elde edildi. Hastalar yaşlarına göre gruplandırıldı. Türkiye'nin 7 [Ege (E), Marmara (M), Karadeniz (K), Iç Anadolu (I), Doğu Anadolu (D), Güney Doğu Anadolu (G), Akdeniz (A)] bölgesinden ve Balkanlardan (B) İmir iline göç eden nüfus sayıları 2008 Adrese Dayalı Nüfus Kayıt Sistemi (ADNKS) sonuçlarından elde edildi. Ege bölgesindeki Izmir dışındaki diğer illerden Izmir'e göç edenler Ege (E) olarak değerlendirildi. Tüm hastalar ayrıca yaşadıkları yerlere göre köyde ve kentte yaşayanlar olarak ayrıldı. Bu bilgilere nüfusa kayıtlı oldukları adres bilgilerinden ulaşıldı.

Izmir iline göç ile gelenlerin nüfus sayılarına göre dağılımlarına (2008 ADNKS sonuçlarına göre) ulaşıldı. Her bölge için elde edilen oranlar, diğer bölgelerle karşılaştırılıp istatistiksel olarak ki kare testi kullanıldı. p<0.05 değeri anlamlı kabul edildi.

Yaş grupları 20-29, 30-39, 40-49, 50-59, 60-69, 70-79 ve 80 yaş üzeri olarak belirlendi. Hastaların cinsiyet ve yaş dağılımları, yaş grupları arasındaki farklar, kent ve köyde yaşam dağılımları ki-kare testi ve Pearson Korelasyon testi kullanılarak incelendi.

Endoskopi ile mide kanseri tanısı için alınan biyopsi materyali \%10 formalin solüsyonu içerisinde histopatolojik incelemeye gönderildi. Alınan materyaller hematoksilen-eozin boyası ile boyanarak patolojik inceleme yapıldı. Patoloji sonuçları da kaydedildi.

\section{BULGULAR}

21600 farklı hastaya yapılan üst gastrointestinal sistem endoskopisinde 388 hastada mide adenokarsinomu saptandi. Bu hastaların 260'ı (\%67) erkek, 128'i (\%33) kadın olup ( $\mathrm{p}=0.002)$, erkeklerde mide kanseri görülmesi kadınlardan daha yüksek oranda idi. Ortalama yaş kadınlar için $63 \pm 14$ yll, erkekler için $61 \pm 16$ yll idi. Kadınlarda mide kanseri görülme yaşı erkeklere oranla daha yüksekti. Midenin tutulum yerine göre tüm hastaların 270'i (\%70) distal, 118'i (\%30) proksimal lokalizasyonlu mide kanseri idi $(\mathrm{p}=0.002)$.

Beş hastada polipoid yapıda, geri kalan (383) hastalarda ise ülser veya ülserovejetan kitle lezyonu mevcuttu.

Çalışmamızdaki hastaların yaş gruplarına göre dağılımlarl: 20-29 yaş grubunda 7 kişi (\%1.8), 30-39 yaş grubunda 25 kişi (\%6.4), 40-49 yaş grubunda 37 kişi (\%9.5), 50-59 yaş grubunda 84 kişi (\%21.7), 60-69 yaş grubunda 89 kişi (\%22.9) 70-79 yaş grubunda 114 kişi (\%29.4), 80 yaş üzerinde 32 kişi (\%8.3) mevcuttu. 
Yaş grupları arasında hastalar birbirleri ile karşılaştırıldığında ise hastaların \%73'ü (n=287) 50-79 yaş aralığında saptandı. 50 yaş altında 101 hasta (\%27) mevcuttu. Her iki yaş grubuna giren hasta sayıları karşılaştırıldı ğında 50 yaş üzerinde mide kanseri görülme sıklığı istatistiksel olarak anlamlı derecede daha yüksek saptandı ( $\mathrm{p}=0.001)$. Vakaların yaş gruplarına göre dağılımları incelendiğinde; 50-59 yaş grubunda \%21.7 ( $\mathrm{p}=0.012$ ), 60-69 yaş grubunda \%22.9 ( $\mathrm{p}=0.012), 70$ 79 yaş grubunda \%29.4 ( $\mathrm{p}=0.001)$ mide kanserli vaka gözlenirken, bu oranlar 50 yaş altındaki yaş gruplarında 20-29 yaş grubunda 7 kişi $(\% 1,8), 30-39$ yaş grubunda 25 kişi $(\% 6,4)$, 40-49 yaş grubunda 37 kişi $(\% 9,5)$ ile karşılaştırıldığında istatistiksel olarak anlamlı yüksek saptanmıştır.

Izmir'de ikamet eden mide kanserli hasta sayısı 305 kişiydi. Diğer bölgelerde ikamet edip, hastanemize gelen hastaların sayısı ise 83 idi. Hastaların nüfus kayıtlarına göre kayıtlı oldukları iller ve bölgelere göre sayıları, her bir bölge için İmir'de yaşayan kişi sayısına oranları ayrı ayrı hesaplandı (Tablo 1). Buna göre çalışmamızda mide kanseri görülme sıklığı en fazla 21 kişi (27/100 000) ile Balkan (B) ülkelerinden gelenler ve 85 kişi (26/100 000) ile Doğu Anadolu Bölgesi'nden gelenler (D) arasinda bulundu. Mide kanseri en az görülme oranları 105 kişi (\%5) ile Ege Bölgesi'nden (E), 21 kişi (\%8) ile İç Anadolu Bölgesi'nden (I), 20 kişi (\%11) ile Güneydoğu Anadolu Bölgesi'nden ( $G$ ), 13 kişi (\%9) ile Marmara Bölgesi'nden (M) ve 9 kişi (\%11) ile Akdeniz Bölgesi'nden (A) göç edenlerde tespit edildi. Bu sonuçlara göre, D ( $p=0.001), K(p=0.015)$,
B ( $\mathrm{p=0.001)} \mathrm{bölgeleri} \mathrm{ile} \mathrm{diğer} \mathrm{bölgelerdeki} \mathrm{mide} \mathrm{kanseri} \mathrm{gö-}$ rülme oranları karşılaştırıldığında, istatistiksel olarak bu bölgelerde anlamlı derecede yükseklik saptandı. A ( $\mathrm{p}=0.090)$, $E(p=0.063), G(p=0.053)$ bölgelerinden göç edenlerde ise mide kanseri görülme oranları diğer bölgelere göre daha düşük olmasına rağmen istatistiksel olarak anlamlı bulunmadı.

Il merkezinde yaşayan mide kanserli hastalar (276 kişi) il merkezinde yaşayan toplam nüfusa oranlandığında, mide kanserinin kentte görülme oranı \%8.7 saptandı. Kırsal alandaki mide kanserli hastalar (29 kişi) kırsal alanda yaşayan toplam kişi sayısına oranlandığında ise, kırsalda mide kanseri görülme oranı \%5.1 idi (Tablo 2). Bu sonuç mide kanserinin kentte görülme oranının kırsal kesime göre istatistiksel olarak anlamlı derecede yüksek olduğunu gösterdi ( $\mathrm{p}=0.005)$. Mide kanserinin kentte yaşayanlar arasında kırsal alanda yaşayanlara göre daha yüksek oranlarda olduğu saptandı. 161 (\%41.5) hastada ilk tanı anında görüntüleme yöntemleri (bilgisayarlı tomografi, magnetik rezonans, pozitron emisyon tomografisi) ile metastatik veya lokal ileri evre hastalık olduğu belirlendi.

\section{TARTISMA}

Hastanemiz 3. basamak sağllk kurumu olduğundan hastanemize il dışından gelen hastalar mevcuttu. Hastalarımızın büyük çoğunluğu (305 kişi) ise İmir ilinde ikamet etmekteydi. Bu çalışmada mide kanseri görülme sıklığı açısından Balkan ülkelerinden (27/100 000 kişi) ( $p=0.001)$ ve Doğu Anadolu Bölgesinden (26/100 000 kişi) ( $p=0.001)$, Karadeniz Bölge-

\section{Tablo 1. İzmir'de ikamet eden nüfusun kayıtlı olduğu bölgelere göre hastaların dağılımı}

$\begin{array}{lcccc}\text { Bölge } & \text { Olgu Sayısı } & \text { İzmir'deki Nüfus } & \text { Hasta/100 000 kişi } & \text { p } \\ \text { Akdeniz Bölgesi (A) } & 9 & 81714 & 11 & 0.090 \\ \text { Doğu Anadolu Bölgesi (D) } & 85 & 322329 & 26 & 0.001 \\ \text { Ege Bölgesi (E) } & 105 & 2077232 & 5 & 0.063 \\ \text { Güneydoğu Anadolu Bölgesi (G) } & 20 & 179345 & 11 & 0.053 \\ \text { İ̧ Anadolu Bölgesi (I) } & 21 & 258029 & 8 & 0.090 \\ \text { Karadeniz Bölgesi (K) } & 31 & 181249 & 9 & 0.015 \\ \text { Marmara Bölgesi (M) } & 13 & 135444 & 27 & 0.083 \\ \text { Balkan Ülkeleri (B) } & 21 & 76470 & 0.001\end{array}$

Doğu Anadolu Bölgesi (D) ( $\mathrm{p}=0.001)$, Karadeniz Bölgesi (K) ( $\mathrm{p}=0.015)$, Balkan Ülkeleri (B) ( $\mathrm{p}=0.001)$ ile diğer bölgelerdeki mide kanseri görülme oranlarının karşılaştııılmasında istatistiksel olarak bu bölgelerde anlam yükseklik saptandı Akdeniz (A) (p=0.090), Ege ( $E)(p=0.063)$, Güneydoğu Anadolu $(\mathrm{G})$, ( $\mathrm{p}=0.053)$ bölgesinden göçenlerde ise mide kanseri görülme oranları diğer bölgelere göre daha düşük olmasına rağmen istatistiksel olarak anlamlı bulunmadı. İstatistik olarak ki kare testi kullanıldı, p<0.05 değeri anlamlı kabul edildi (2008 ADNKS sonuçlarına göre) (29).

Tablo 2. Mide kanserli hastaların kentsel ya da kırsal yerleşimine göre dağılımları

$\begin{array}{lccc}\text { Nüfusun Yerleşimi } & \text { İzmir Nüfusu } & \text { Hasta Sayısı } & \text { (Hasta/Nüfus)x100 000 } \\ \text { Kentsel } & 3175133 & 276 & 8.7 \\ \text { Kirsal } & 564220 & 29 & 5.1\end{array}$

Izmir il sınırları içinde yaşayan nüfusun yerleşim yerlerine göre hastaların dağılımı. Ki kare kentsel alanda yaşayanlarda gastrik kanser görülme oranları, kırsal alanda yaşayanlara göre yüksek bulundu ( $\mathrm{p}=0.005)$ (2008 ADNKS sonuçlarına göre) (28). 
si'nden (17/100 000 kişi) ( $\mathrm{p}=0.015)$ Izmir'e göçenler ile diğer bölgelerden Izmir'e göç edenler arasında anlamlı derecede farklılık saptandl.

Mide kanseri etiyolojisinde genetik faktörler ve beslenme tarzlarında yöresel değişiklikler olması nedeniyle, mide kanseri görülme oranlarında bölgesel farklılıklar görülmektedir. Daha önceki çalışmalarda İç Anadolu, Güneydoğu Anadolu ve Doğu Anadolu Bölgesi'nde mide kanseri görülme insidansının diğer bölgelerden daha yüksek oluğu gösterilmiștir (19-22). Bizim çalışmamızda da, diğer çalışmalar ile benzer şekilde mide kanseri görülme sıklığı açısından Doğu Anadolu Bölgesi'nden gelenler arasında yüksek insidansta mide kanseri saptanmış olmasına karşın, İç Anadolu Bölgesi açısından diğer çalışmalar ile farklı sonuçlara ulaşılmıştır. Diğer çalışmalarda Balkan ülkelerinden gelenler arasında mide kanseri görülmesi açısından değerlendirilme yapılmamıştır

Mide kanseri Türkiye genelinde erkeklerde akciğer kanserini takiben ikinci sıklıkta (9.6 kişi/100 000), kadınlarda ise meme ve kolon kanserinden sonra üçüncü sıklıkta (5.7 kişi/100 000) görülmektedir (20). Bizim çalışmamızda Ege Bölgesi (5/100 000), Iç Anadolu (8/100 000), Marmara (9/100 000) Bölgesi'ndeki mide kanseri oranları önceki verilere yakın olup, Doğu Anadolu, Karadeniz Bölgesi ve Balkan ülkelerinden gelenlerde (sirasıyla, 26/100 000, 17/100 000, 27/100 000) önceki verilere göre yüksek oranlarda mide kanseri görülmüştür.

Doğu Anadolu Bölgesi'nden ve Balkan ülkelerinden göç edenlerde mide kanseri daha fazla görülürken, Ege Bölgesi’nde yaşayanlarda daha az görülmektedir. Bu farklılık herediter bir farlllık mı yoksa yöreye özgü beslenme ve çevresel faktörler mi rol oynamaktadır? sorusunu gündeme getirmektedir. Bizim çalışmamızda, hastanın doğumunda kayıtlı olduğu il temel alınmıştır. Hastanın anne ve babası farklı illerde yaşıyor veya farklı illerde nüfusa kayıtlı olabilir. Retrospektif bir çalışma olduğu için verilere kayıt bilgilerinden ulaşılmıştır. Bu bakımdan yeni prospektif çalışmaların yapılması, bu konuda daha sağlıklı veriler elde edilmesini sağlayabilir.

Italya'da yapılan bir çalışmada, akrabasında (birinci derece) mide kanseri bulunanlarda mide kanseri görülme oranları yüksek saptanmış olup, bu durum herediter nedenler ya da aileden gelen beslenme alışkanlıkları ile ilişkili bulunmuştur (23). Japonya'dan ve Çin'den Amerika'ya göç edenler arasında yapılan bir araştırmada ise, Amerika'da yaşayan Japon'larda Amerika'lı beyazlardakine oranla 3 ile 6 kat fazla oranda mide kanseri görülmüştür. Aynı çalışmada Çin'li erkeklerde mide kanseri Amerika'lllarla aynı oranda görülürken, Çin'li kadınlarda ise Amerika'lllardan 2 kat fazla oranda mide kanseri görülmüştür (24). Mide kanseri etiyolojisi arasında özellikle herediter ve çevresel faktörler rol oynamaktadır. Mide kanserinde kentsel ve kırsal nüfuslar arasında insidans ba- kımından da farklılıklar vardır. Bizim çalışmamızda kentsel bölgelerde yaşayanlarda mide kanseri 8.7/100 000 kişi iken, kırsalda 5.1/100 000 kişi olarak bulundu. Mide kanserinin kentsel kesimde yaşayanlarda daha fazla görüldüğü tespit edildi ve bu sonuç istatistiksel olarak anlamlı idi.

Mide kanserinde bugün için en çok üzerinde durulan etiyolojik faktörlerden biri diyettir. Özellik Doğu Anadolu bölgesinde (Van ilinde) yapılan bir çalışmada, besinlerde bulunan benzo(a)piren ve 1,2-benzantrasen maddelerinin kardiya kanseri riskini arttırdığı gösterilmiştir. Ayrıca bu çalışmada mide kanseri hastaları kontrol grubuyla karşılaştırıldığında, daha az taze meyve ve sebze tüketmelerine rağmen daha fazla tuzlu yiyecek tükettikleri bildirilmiştir. Aynı çalışmada, düşük sosyo-ekonomik şartlara sahip kişilerde mide kanseri görülme sıklığının daha yüksek olduğu da vurgulanmıştır (25).

Yalçın S ve arkadaşları yaptıkları bir çalışmada ailesinde mide kanseri olanlarda mide kanseri görülmesi oranını \%12.2 olarak bulmuşlardır (26). Bu sonuç da ülkemizdeki mide kanseri etiyolojisinde genetik özelliklerin de önemli bir neden olduğunu düşündürmüştür. Bir başka çalışmada ise ailelerin beslenme şekilleri ve Helicobacter pylori enfeksiyonunun yüksek prevalansda olmasının mide kanseri için önemli risk faktörleri olduğu bildirilmiştir (27).

Bizim çalışmamızda hastaların büyük çoğunluğu mide adenokarsinomu olduğu için sadece mide adenokarsinomları dahil edilip, diğer mide kanseri patolojik tiplerine sayıca az rastlanmıştır. Adenokanser dışındaki diğer patolojik mide kanseri tipleri için sayıca azlık nedeniyle hasta sayılarının bölgelere göre dağılımları yapılamamış, bu patolojik tipler için istatistiksel değerlendirme de sınırlı olmuştur. Bu nedenle çalışmamıza sadece mide adenokanserleri dahil edilip, diğer mide kanseri patolojik tipleri çalışma dışı bırakılmıştır. Bu bilgilerin araştırılması için çok geniş kapsamlı ve çok merkezli araştırmalara ihtiyaç vardır.

Çalışmamızda diğer kısıtlayıcı faktör ise hastaların nüfus kayıtlarına ve adres bilgilerine göre retrospektif olarak tarama yapılmış olmasıdır. Bununla ilgili de hastaların bölgesel yerleșimleri, göç ettikleri şehir ve bölgelerle ilgili kayıtların da olduğu ve beslenme özelliklerini de içine alan yeni araştırmaların yapılması daha doğru ve güvenilir sonuçlar elde edilmesini sağlayabilir.

Izmir'de yaşayan, fakat Izmir'e Anadolu'nun başka illerinden göç etmiş kişilerde, kendi illerine göre daha farklı oranlarda mide kanseri oluştuğunu göstermek ve dolayısıyla yeme alışkanlığının genetik yapıyla olan ilişkisini ortaya koymak için, her il ve bölge bazında yeni araştırma yapmak da gereklidir.

Önceden yapılmış çalışmalar daha çok Doğu Anadolu Bölgesi'nde özellikle de Van'da yapılmış olup bu çalışmada Türkiye'de mide kanseri görülme insidansi erkeklerde 12.2/100 000 kişi, kadınlarda 6.4/100 000 kişi olarak bildirilmiştir 
(20). Çalışmamızda, Doğu Anadolu Bölgesi'nden Izmir'e gelenler arasında mide kanseri sıklığı 26/100 000 kişi olarak bulunmuștur. Bizim çalışmamız hastaneye başvuran hastalar arasından yapıldığı için bu değerlerin daha yüksek olarak çımış olması muhtemeldir.

Tuncer I ve arkadaşlarının yaptığı çalışmada 4763 hasta içinden endoskopik görünüm ve histopatolojik inceleme ile mide kanseri tanısı almış 508 hasta çalışmaya dahil edilmiş olup, \%10.6 mide kanseri vakası bulunmuştur (20). Bizim çalışmamıda ise 21600 üst gastrointestinal endoskopisi yapılan hastanın 388'inde mide kanseri tespit edildi. Bu oran \%0.7 olarak tespit edildi. Bu bakımdan hastanemizde toplam mide kanseri tanısı alan hastaların oranı Van'daki (20) çalışmayla karşlaştırıldığında Van'daki oranlar bizim sonuçlarımıza göre daha yüksek olarak görüldü. Tuncer I ve arkadaşlarının yaptığı çalışmada Van gölü ve çevresinde mide kanserinin daha yüksek sıklıkta olduğu gözlenmiştir. Bizim çalışmamızda da Doğu Anadolu Bölgesi'nden Izmir'e göç edenler arasında mide kanseri görülme oranı daha yüksek saptanmıştır.

\section{KAYNAKLAR}

1. Jemal A, Bray F, Center MM, et al. Global cancer statistics. CA Cancer J Clin 2011;61:69-90.

2. Parkin DM, Bray F, Ferlay J, Pisani P. Global cancer statistics, 2002. CA Cancer J Clin 2005;55:74-108.

3. Parkin DM, Whelan SL, Ferlay J et al. (eds). Cancer Incidence in Five Continents, Volume VII. IARC Scientific Publications No. 143. Lyon, France: International Agency for Research on Cancer 1997.

4. Nomura A. Stomach cancer. In Schottenfeld D, Fraumeni JF (eds): Cancer Epidemiology and Prevention, $2^{\text {nd }}$ edition. New York, NY: Oxford University Press 1996:707-24.

5. The EUROGAST Study Group. An international association between Helicobacter pylori infection and gastric cancer. Lancet 1993;341:1359-62.

6. South Australian Cancer Registry. Epidemiology of Cancer in South Australia. Incidence, Mortality and Survival, 1977 to 1999. Incidence and Mortality, 1999. Adelaide, Australia: Openbook Publishers 2000.

7. Bruckner HW, Morris JC, Mansfield P. Neoplasms of the stomach. In Bast RC, Kufe DW, Pollock RE et al. (eds): Cancer Medicine, $5^{\text {th }}$ edition. Hamilton: BC Decker 2000;1355-90.

8. American Cancer Society. Facts and Figures 2001. Atlanta, GA: American Cancer Society 2001

9. Oral A, Sahin T, Turker F, Kocak E. Relationship between serum uric acid levels and nonalcoholic fatty liver disease in non-obese patients. Medicina (Kaunas) 2019;55:pii: E600.

10. Uzel M, Sahiner Z, Filik L. Non-alcoholic fatty liver disease, metabolic syndrome and gastric cancer: Single center experience. J BUON 2015;20:662

11. Özaydın ANG, Çalı \$̧, Türkyılmaz AS, Hancıoğlu A. Marmara Sağlık Eğitim ve Araştırma Vakfı, 2007. TURHEP Türkiye Helicobacter pylori Prevalans Araştırması 2003 (TURHEP Turkey Helicobacter pylori Prevalence Survey 2003), Istanbul.

12. Ozden A, Dumlu S, Soylu K, et al. The prevalence of Helicobacter pylori infection in a defined healthy population in Turkey. Hellenic J Gastroenterol (Suppl). First United European Gastroenterology Week, Athens, 1992.

13. Us D, Hascelik G. Seroprevalence of Helicobacter pylori infection in an asymptomatic Turkish Population. J Infect 1998;37:148-50.

14. Imai S, Koizumi S, Sugiura M, et al. Gastric carcinoma: monoclonal epithelial malignant cells expressing Epstein-Barr virus latent infection protein. Proc Natl Acad Sci U S A 1994;91:9131-5.
Çaycı HM ve arkadaşlarının Bursa'da yaptığı bir çalışmada 77 adet mide kanseri nedeniyle ameliyat olan hastanın kayıtları retrospektif olarak incelenmiştir. Hastalar arasında ileri yaş

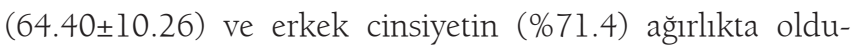
ğu görülmüştür. Yaş grupları değerlendirildiğinde, sadece 2 (\%2.6) olgunun 40 yaşından küçük olduğu, 24 (\%31.6) olgunun ise 70 yaşından büyük olduğu bulunmuştur (28). Bizim çalışmamızda da ileri yaş gruplarında mide kanserinin anlamlı derecede daha yüksek sıklıkta görüldüğü doğrulanmıştır.

Kentsel ve kırsal kesimde yaşayanlar arasında rafine yiyecek kullanımı, taze sebze ve meyve kullanımı ve taze yiyeceklere ulaşıması konusunda farklılıkların olması da beslenme tarzının mide kanseri oluşumunda önemli olduğu görüşünü desteklemektedir. Bizim çalışmamızda bölgeler arasında farklı sonuçların çıması da, mide kanseri gelişiminin bu bölgelerde yaşayanlarda ve buralardan Izmir'e göç eden kişilerde diyet alışkanlıklarının eskisi gibi devam etmesi ve bu kişilerin ailesel özellikleri ile ilişkili olduğunu düşündürmüştür. Ancak bu konuyla ilgili yeni ve daha geniş kapsamlı çalışmalara ihtiyaç vardır.

15. Colquhoun A, Arnold M, Ferlay J, et al. Global patterns of cardia and non-cardia gastric cancer incidence in 2012. Gut 2015;64:1881-8.

16. Polkowski W, van Sandick JW, Offerhaus GJ, et al. Prognostic value of Laurén classification and c-erbB-2 oncogene overexpression in adenocarcinoma of the esophagus and gastroesophageal junction. Ann Surg Oncol 1999;6:290-7

17. Kaneko S, Yoshimura T. Time trend analysis of gastric cancer incidence in Japan by histological types, 1975-1989. Br J Cancer 2001;84:400-5.

18. Oliveira C, Suriano G, Ferreira P, et al. Genetic screening for familial gastric cancer. Hered Cancer Clin Pract 2004;2:51-64.

19. Firat D, Celik I. Cancer statistics in Turkey and in the World, 1993-1995. Turkish Association for Cancer Research and Control, Ankara, 1998.

20. Tuncer I, Topcu N, Ugras S, et al. Van gölü havzasında gastrointestinal kanserlerin dağılımı; 1002 olgunun analizi. T Klin J Gastroenterohepatol 2003;14:161-6.

21. Yalcin S. Gastric cancer in Turkey-A bridge between West and East. Gastrointest Cancer Res 2009;3:29-32.

22. Karaoğuz H, Içli H. Cancer problem in Türkiye. J Ankara Med School 1993; 15:547-58

23. Palli D, Galli M, Caporaso N E, et al. Family history and risk of stomach cancer in Italy, Cancer Epidemiol Biomarkers Prev 1994;3:15-18.

24. Kamineni A, Williams MA, Schwartz SM, Cook LS, Weiss NS. The incidence of gastric carcinoma in Asian migrants to the United States and their descendants. Cancer Causes Control 1999;10:77-83.

25. Türkdoğan KM, Dağoglu G, Akman N, et al. Dietary benzo(a)pyrene and 1,2-benzanthracene levels in an endemic upper gastrointestinal (oesophageal and gastric) cancer region of Turkey. J Nutr Environ Med 2003;13:103-8.

26. Yalcin S, Gümüş M, Kilickap S, et al. End-of-study results of Turkish gastric cancer patients from the global REGATE study. J BUON 2014;19(2):377-87

27. Bor S, Vardar R, Ormeci N, et al. Prevalence patterns of gastric cancers in Turkey: model of a developing country with high occurrence of Helicobacter pylori. J Gastroenterol Hepatol 2007;22:2242-5.

28. Çaycı HM, Erdoğan UE, Çantay H, et al. Mide kanseri deneyimlerimiz: Tanı ve tedavide geç mi kalıyoruz? Akademik Gastroenteroloji Dergisi 2017;16:6-11.

29. TUIK 2008 ADNKS sonuçları 